
TRADITIONALISM AND THE IDEA OF PROGRESS: A CASE FOR
IDEOLOGICAL MOBILIZATION IN COMMUNIST CHINA

\author{
Dennis M. Ray \\ California State College at Los Angeles
}

Economic development is not a one-dimensional process whereby a country's productivity and Gross National Product increase, machines are substituted for men, and new products appear. Development is characterized by the creation of a new society.

For economic development to come about, changes must occur in traditional man's perception of his social and physical environment and his relationship to it. This is essential if traditional man and his society are to break out of the stability and fatalism of poverty, escape from superstition and ignorance, and overcome the inertia of social custom and vested interest.

The purpose of this article is to examine how ideological mobilization in Mao Tse-tung's China has functioned to undermine traditional impediments to economic development and instil the idea that progress is both possible and desirable.

The politics and economic programs of Mao Tse-tung have long been associated with ideological mobilization. The clearest example of ideological mobilization was the Great Leap Forward (1958-1959) when the people were called upon by political activists to undertake a vast range of economic, political, military, social, and cultural programs. The driving impetus of this activity was the ideological exhortation of the Party cadres.

One of the most interesting analyses of ideological mobilization in China has been offered by Robert Jay Lifton (1968:99-126), a psychologist. Lifton uses the term "psychism" to describe China's "attempt to achieve control over one's external environment through internal or psychological manipulations" (1968:32). According to Lifton, psychism was dominant during the Great Leap Forward, for this was a period when China proclaimed that it would soon overtake some of the capitalist countries in industrial and agricultural production while discovering a short-cut to the communist utopia. Talk of an "uninterrupted" or "permanent" revolution suggested the "total mobilization of faith" and the reliance on ideology. Lifton writes that the Great Leap was characterized by the assumption that "one could ignore the intellectual and mechanical requirements of technology and depend instead upon human will"l(1968: 104). Lifton quotes from the Chinese press to illustrate his point.

Many living examples show that there is only unproductive thought, there are no unproductive regions. There are only poor methods for cultivating the land, there is no such thing as poor land. Provided only that people manifest in full measure their subjective capacities for action, it is 
possible to modify natural conditions.

I'he entire tone of the Great Leap suggests a vision of "immortal Chinese revolutionary and cultural substance" overcoming the technical requirements of industrialism (Lifton, 1968:105). However, ideological mobilization during the Great Leap "politics takes command" and "reliance on the mass line" - led to considerable disruption of the administrative and economic system.

Technicians and engineers were humiliated by the existence of a situation under which experts had to listen to non-experts in technical matters, scientific laws were replaced by political demands, and production fell into the hands of a group of "fanatics" (Lifton, 1968:105, quoted from Chao, 1964).

Here we see, according to Lifton, the consequences of the Maoist assumption that "revolutionary enthusiasm and ideological purity could make up for the lack of technical competence and material means"(Schram, 1966:294).

The tone of Lifton's analysis of psychism is critical. He, like most other students of contemporary Chinese affairs, views ideological mobilization as an aberration which can only be counter-productive to the goals of economic and political development. It is ironic, however, that at a time when the Maoist emphasis on ideological mobilization is being criticized, some economists are beginning to recognize the importance of subjective attitudes in the developmental process.

Economic development is not a one-dimensional process whereby a country's productivity and GNP increase, machines are substituted for men, and new products appear. Development is characterized by the creation of a new society. Joseph $\mathrm{J}$. Spengler, an economist, assigned a central role to ideas and beliefs when he suggested that the state of a people's politico-economic development, together with its rate and direction, depends largely upon what is in the minds of its members, particularly the elites, and reflects in part their conceptions of the universe (Spengler, 1961:4; for similar conceptions of the problem see Northrop, Jaspers, Monlin). To reformulate Spengler's hypothesis, it is submitted here that economic development can come about only as a result of changes in man's perception of his social and physical environment and his relationship to it. This must occur if traditional man and his society are to break out of the stability and fatalism of poverty, escape from superstition and ignorance, and overcome the inertia of social custom and vested interest. If traditional man does not begin to prize change and presuppose its possibility, to accumulate and apply development oriented scientific knowledge, to possess habits, beliefs and values which are compatible with industrial society, then little or no development will occur.

While in the abstract many Western observers of China have long recognized the need to create a new society in China, they seem unable to acknowledge the efficacy of Mao Tse-tung's concrete steps to put that goal into practice. For example, the noted historian John King Fairbank writes that China was traditionally a world in itself, not a nation among nations.

The problem of China has been therefore how to reorganize an entire society, its institutions and customs, ideas and ideals. The Chinese people have been challenged to think differently and act differently, speak a new national language and read a new written language, and really remake themselves completely (1962:13). 
While recognizing this need, he can do no more than admit that "communism has seemed to prove a way of meeting this challenge, but on an arbitrarily selective basis

(Fairbank, 1962:13). What is arbitrary in this context lies in the eyes of the beholder. We must come to terms with the developmental context of Mao Tse-tung's thought without imposing our own ideological and cultural values on the question. If we fail to do this, we will continue to perceive China's ideological mobilization as an aberration. The purpose of this article is to examine the role of ideological mobilization in overcoming certain obstacles to economic development. Specifically, it will be argued that ideological mobilization can help weaken the influence of Chinese culture and tradition as these retard development and provide the "will" or "incentive" for change in Chinese society.

\section{Chinese Tradition}

Traditional society is extremely stable. China was a land-oriented civilization which was almost entirely preoccuppied with an agrarian mode of life, which found its values in stability, conservatism, and continuity. Chinese society grew over thousands of years on the basis of agricultural self-sufficiency rather than trade or industry. Chinese society was continental and landlocked on three sides; this cut China off from ready access to Europe or the Middle East. While bordered on one side by the sea, China turned inwards instead of becoming a seafaring nation. From ancient times, the Chinese people have been immobile and tied to intensive cultivation on small plots of 1 and. Physical remoteness coupled with a strong sense of superiority and perfection neutralized most impulses for change and innovation. "Why should individuals who were perfectly content with their existence," asked Bertrand Russel1 (1922), "strive for economic development?" Even at the end of the nineteenth century when the Chinese were suffering "defeat after defeat at the hands of the West" they still maintained "almost untouched the myth of their own superiority and the assurance of their own adequacy (Rowe, 1959:27). And why not, no other society of comparable size, duration or influence had ever existed. It is not surprising to find the Chinese regarding themselves as the on1y custodians of civilization and their country the hub of the world. Prior to the nineteenth century there was no historical experience that would have lead them to modify the view that they were the "centre of the world (Elegant, 1963). Unfortunately, Chinese ethnocentrism deadened any interest or curiosity about other civilizations. Thus, when the question of foreign travel was raised in the nineteenth century, many learned Chinese replied that one who knows the Chinese classics has nothing left to learn (Cree1, 1953:9).

Confucianism. Confucianism provided both the institutional and philosophic stability upon which Chinese society rested. For centuries China was the world's most stable system of bureaucratic power. The governing bureaucracy created a vast machine of scholars which perpetuated itself through an examination system. While this class of scholars insured the stability of traditional Chinese society, they also contributed greatly to the inertia and non-adaptability of Chinese civilization. The literati, a class of literary skeptics who were humanistic, secular and rational, lacked the qualities of energy and curiosity which have characterized the intellectual and civil servant classes of modern Western nations.

The literati entered public service by passing a civil service examination stressing memorization of the classics and austerity in literary style. However, passing the "seven-legged" examination and memorizing the Confucian classics hardly prepared the Chinese intelligentsia for the technical innovations required by industrialism or the efficient use of violence required of the modern nation-state. On the contrary, the intellectual energies of the intelligentsia were directed toward reading, contemplation, reflection, and memorization. Thus, Confucianism became a closed system of ideas which defined the mental boundaries within which an individual's 
curiosity and imagination could operate. The Confucian orthodoxy filtered, selected, refined, and interpreted the stimuli of the external world. The effect of this situation may be suggested by considering the effect upon potential Western entrepreneurs and civil servants if they had conceived, analyzed, and implemented policy in terms of classical Christian dogma. How far would economic development have progressed if potential entrepreneurs had spent hours memorizing the Bible, developing a literary style for expressing Biblical quotations, and even more time contemplating the teachings of Christ? Such a person might have been a morally superior individual, but he would not have become the dynamic force behind the economic transformations of our age.

The conservatism of Chinese society also had its roots in the class interests of the literati, who placed the preservation of their class interests above Chinese sovereignty and above the requirements of modernization. The class interests of the literati were founded on a maintenance of the status quo. Extensive contact with Western technology and ideas could only undermine this status quo. Chinese Communism has, of course, expressed a deep and occasionally violent antagonism towards the traditional elite of China. In rejecting the traditional Chinese social system, the thought of Mao Tse-tung also rejects Western capitalism. Thus, the Marxist components of Mao's thought explain the downfall of traditonal Chinese society as the victim of capitalist imperialism. In so doing, the thought of Mao can exploit the widespread sense of humiliation felt in China (Pye, 1968:chap.5) by attacking the social classes, institutions, and social philosophies which made that humiliation possible. 3

Man's relationship to the universe. In China, as in other traditional societies, the individual's capacity to understand or control the forces which shape his life are highly restrained or even non-existent. Life is perceived as a mystery in a profound sense in which it is not to the modern man. Since the traditional individual merely takes for granted that the phenomena of the world around him are arbitrary and unamenable to analysis, his salvation lies in persuading the spiritual authorities to intervene on his behalf (Yang, 1967). F.M. Watkins has written that pre-industrial man:

lives in a stable and tradition dominated world, a closed society, where external forces seem to determine the conditions of human existence. To perceive and conform to the requirements of these extra-human forces is the primary problem (1951:570).

Perhaps the best expressions of how the Chinese traditionally sought to conform to the requirements of extra-human forces can be found in Chinese art and literature (Soper, 1956; Hightower, 1950). Throughout Chinese culture, particularly in Chinese poetry and painting, we find an awareness of the beauty and mystery of Nature (Bodde, 1965:32). Man is always present in the cosmic view of the Chinese but never in an assertive or dominant place. Never are the mountains, rivers, and forests of the great Chinese landscape painters mere decorative backdrops for man and his activities, as so often is the case in Western art. But Chinese landscapes are never empty and seemingly uninhabited wildernesses; invariably they possess tiny yet distinct human figures, a fisherman in his boat, a woodcutter, or a recluse sitting in contemplation on a rock. Man's relationship to the cosmic order in traditional China stands in stark contrast to conquest and pollution of the natural environment in an industrial society (Cf. Babbitt, 1919:270-4). While Western stil1-1ife painters portray the string of slaughtered game, the platter of plucked fruit, and the bowl of cut flowers, animals, birds, insects, and plants, in Chinese paintings are always shown alive and in their natural surroundings. 
Fatalism. While Western man has exalted the human personality by demonstrating man's command over nature, Chinese attitudes were characterized by a high degree of fatalism. This fatalism inhibited the rise and diffusion of new ideas and methods. It is not surprising that new ideas and new methods which threatened to undermine the authority of the traditional elite and the beliefs and stable institutional relationships of all Chinese were viewed with panic, confusion, and resistence. An M.I.T. report on modernization captured, in more general terms, the source of such resistance.

The cultural and religious life of traditional societies and the values they elevated, varied widely. Generally, however, they formed a coherent pattern, giving men a reasonable orderly rationale for the relatively stable round of life they faced, at whatever level in the society they found themselves. They provided a set of relationships of men to one another and to the world about them which gave them a degree of security in facing their appointed destiny within the traditional structure (1960:15).

The Chinese have traditionally had a "somewhat mystical faith in the powers of history to bring about change" (Pye, 1968:127) within an enduring philosophical and institutional framework. Consequently, China was a land of rebellion not revolution. Historical change was cyclical not linear. Time inevitably would bring about the rise and fall of all things, including families, nations, and empires. The cyclical pattern of history and man's fate remained largely beyond the scope of human will. This may have reflected what an anthropologist has called the "image of limited good" in peasant societies.

Broad areas of peasant behavior are patterned in such fashion as to suggest that peasants view their social, economic, and natural universes - their total environment - as one in which all of the desired things in life such as land, wealth, health, friendship and love, manliness and honor, respect and status, power and influence, security and safety, exist in finite quantity and are always in short supply, as far as the peasant is concerned. Not only do these and all other "good things" exist in finite and limited quantities, but in addition there is no way directly within peasant power to increase the avai1able quantities (Foster, 1965:296).

This "image of limited good" generated the fatalism and perhaps much of the inertia which has characterized Chinese civilization. The distribution of the good things in this life was a product of immutable patterns of history and not subject to linear change.

In sharp contrast to an inner dependence on maintaining traditional values and a pervasive assumption of scarcity, the thought of Mao Tse-tung glorifies change and social transformation. The thought of Mao Tse-tung, for example, has done much to transform the Chinese attitude towards nature. As expressed in a song popular in 1958:

There's no Jade Emperor in heaven, No Dragon King on earth.

I am the Jade Emperor,

I am the Dragon King.

I order the three mountains and five peaks:

"Make way! Here I come!" (Strong, 1964). 
This suggests a fundamental change in how the Chinese perceive the world and man's rclationship in it. While the Chinese used to bring their lives into harmony with the nature forces of this universe, China under the influence of Mao is now attempting to control, manipulate and dominate the forces of nature. In the same sense, the thuught of Mao Tse-tung attacks poverty, superstition, and ignorance. Great numbers of Chinese are coming to despise their situation and are beginning to believe that change is both possible and desirable.

In the West, it was the positive statements of liberalism on the rights of man and the progress of humanity which challenged the old regime. When the problem of man's relation to the world and to worldly activity was seen in the light of Puritanism, the foundation for the economic transformation of Western society had been laid. Puritanism opened the door to modern society by giving religious sanction to material pursuits in this world. In China, the primary way in which this has been achieved has been through ideological mobilization. As Alexander Eckstein has observed:

Mass indoctrination and mobilization are required to break the inertia of the masses, the inertia built into the very fabric of society and the structure of the economy, and to break the dead weight of tradition $(1970: 486)$.

The thought of Mao Tse-tung has functioned to transform the perceptions of the Chinese and to infuse them with a spirit of radicalism, zeal, and commitment sufficient to break the barriers of inertia, stagnation, and tradition, which have long been recognized as the major impediments to China's modernization and development. The thought of Mao Tse-tung, as a variant of communist thought, does not come as a successor to capitalism in the twentieth century, but as a substitute for it (Daniels, $1962: 252$ ).

\section{The Idea of Progress}

Breaking the hold of tradition requires something stronger than economic utility, for the promise of an increase in economic production or a better allocation of increasing resources is rarely strong enough to counteract the pull of tradition when the two values stand in conflict. What is needed is a burning faith in a vision of a new society (Gerschenkron, 1962:24). The idea of progress has symbolized this faith and the requisite perceptual changes essential for breaking the stability and fatalism of traditional society. Unfortunately, nothing is more foreign to the Confucian spirit than the idea of progress (Balazs, 1964:32).

In Western thought the idea of progress derived from the convergence of two great ideas which seem divergent and even antagonistic (Tuveson, 1964). It was the convergence between science and the revival of the belief in a literal millennial end to history which produced the idea of progress which in turn created in Western society a "profound revolution in social attitudes and beliefs" (Tuveson, 1964). Without faith in the secular millennialism that we know as progress, Western society might never have arisen to its current level. When millennialism was combined with science, Western man came to believe that advances in technology and other material aspects of culture also brought spiritual improvement. As man controls nature, he becomes "better and better" (Tuveson, 1964:vi).

The idea of progress became a "faith" signifying confidence in a new kind of Providence. Technological and economic endeavors would lead inevitably to a happy ending in which the tensions and evils of the human race would be resolved. This "faith" was not a matter of empirical verification, rather it was a self-evident 
truth. This "faith" marked a significant change from the Renaissance ideas of progress, for it made advancement of the human race not only possible but inevitable since it was prophesied in God's word. "God's method is progressive," as one of the eighteenth century millennialists argued on the basis of many scriptural texts (Tuveson, 1964).

While the basic pattern of the millenialists has become submerged and perhaps lost in the twentieth century, and as the idea of progress has been transported to non-Christian areas, progress as an idea still continues as a spiritual value albeit independent of supernatural Providence. As the world has become secular, so too has the idea of progress. Communism has become on of the primary agents of the idea of progress in the twentieth century. 4 While the utopian element of Mao Tse-tung's political thought is widely recognized, most specialists see Mao's vision not as an agent but as an impediment to industrialism and economic development. We tend to be somewhat aghast at the Maoist blend of technical innovation (science for industrialism) and a utopian vision because we have forgotten the millennial roots of our own vision of progress, having reduced the concept to the mindless expansion of technological gadgetry and quantitative size. We commonly dismiss Mao as an anachronism, an old revolutionary trying to recapture the simple social life of Yenan (See Gayn, 1967: 92-108; Schram, 1969:1-26; Lewis, 1968:449-500), or as an egotist attempting to impose a utopian and impractical vision on Chinese society so that he might achieve "symbolic immortality" (Lifton, 1968). Having lost our own millennial visions, perhaps we resent the proclamation of such visions by a Chinese Communist leader.

The thought of Mao Tse-tung has carried the idea of progress to literally millions of Chinese, stimulating their imangination and challenging the stability and inertia of their daily lives. The Maoist vision of progress is not a matter of caution or qualified calculation; it is absolute, infinite, and utopian in character. It thus counteracts petty indulgence, fear of the future, placid tolerance of existing distress, and unwillingness to take calculated risks. (On the psychological functions of the idea of progress, see Dah1 and Lindblom, 1963:88.) Indeed, faith in the future produces unbounded optimism; faith will bring about a total transformation of society and usher in an era of human perfection.

While it is relatively easy for the detached China specialist to identify the counter-productive manifestations of this faith, we might recall that the Western vision of progress has also contributed to occasional excesses. Does not the United States owe its extensive railway system to the investment blunders of overly optimistic entrepreneurs? A study of entrepreneurship in Meiji Japan suggest the early Japanese entrepreneurs ignored many of the practical difficulties of modernization because of their unbounded optimism. They

gave little weight to the sacrifice they imposed both on the public and on themselves. They had instead some absolute goal, some nondiscounted future value in mind. With their newly acquired faith in the modern era and all that went with it, they could not be shaken by intermediate losses; they knew that in the end they would succeed (Hirschmeier, 1964:199).

Thus, progress becomes a moral imperative, far removed from the utilitarian calculations of individual or even mass economic advantage. In tracing the impact of the idea of progress on both England and Soviet Russia, Professor Adam Ulam captures something of the spirit of this moral imperative: 
If Marxism inherited much of the industrial mania of the early liberal spirit, then this spirit itself was not without a certain one-sideness and intolerance for different standards of value. The source of this intolerance, again a paradox and an analogy to Communism, was not so much class selfishness but precisely the sense of social mission, of performing the necessary and inevitable task of industrialization and modernization, of rescuing England and then the whole world from superstition and backwardness (Ulam, 1964:97).

While it is obvious that the idea of progress occasionally becomes counter-productive, it is the goad to action, the driving impetuous behind modernization.

In contrast to the lethargy and inertia of traditional society, the idea of progress imbues a people with a sense of energy and a will for action. Economic development is sometimes correlated with a "people rushing forth with sudden energy aware of both a new greatness and a new challenge" (Hirschmeier, 1964:207).5 Anyone who has read the history of modern China will immediately recognize that this contrast is precisely what distinguishes contemporary China under communism from China of the Manchu's, warlords, and the Kuomintang. The late French Sinologist Balazs noted the sudden energy of Chinese Communism.

Bringing politics into the daily life of the whole population has radically altered their former habits. Innumerable demonstrations, reunions, marches, committees, meetings, and public trials; theatrical performances, dances, public rejoicings; notices, pamphlets, journals by every possible means official slogans are constantly drilled into every brain. In this way, what was formerly a sluggish, lethargic, undifferentiated mass of people has been shaken up, wakened up, enlivened, turned topsy-turvy, thus releasing an elemental force that will have incalculable consequences (1964:169, emphasis added).

What is this elemental force which is turning Chinese society topsy-turvy?

Benjamin Schwartz's study of Yen Fu gives a most plausible analysis of this elemental force. According to Yen $\mathrm{Fu}$, two forces dominated Western society: (1) the Promothean strain characterized by the exaltation of energy and power both over nonhuman nature and within human society, and (2) social-political idealism represented by such terms as freedom, equality, democracy, and socialism.

The West has exalted human energy in all its manifestations - inte1lectual, moral, and physical. It has identified spirit not with passivity and withdrawal but with energy and assertion. The West has discovered the unlimited nature of human capacities and has fearlessly proceeded to actualize human potentialities undreamt-of in traditional Chinese culture. The terms which come to mind as key-value terms are dynamism, purposive action, energy, assertiveness, and realization of all potentialities (Schwartz, 1964:238).

The idea of progress, later buttressed by the profit motive, social Darwinism, and nationalism has provided the Promothean element in Western society. In Meiji Japan, it was the force of nationalism which unlocked the energy to transform Japanese society. In China the concept of class struggle has undermined the traditional inertia, stability, and emphasis on harmony in Chinese civilization.

Class struggle. Struggle precedes and determines all progress in China. Class struggle is the motivating force for social progress because only through class 
struggle can the old and outmoded patterns of economic life be destroyed. As the Chinese put it, through class struggle "we can smash the dilapidated and decaying mechanisms and systems, and ... replace the old productive formula with a new formula" (Liang Te-nan, 1960:6).6 Liu Shao-ch'i speaking on behalf of the central committee in 1958 said that:

In building a socialist and communist society, we must not only thoroughly extinguish all old systems in which man exploits man and man oppresses man, we must also exterminate all old ideas and habits which stem from these systems and which serve these systems and linger in the heads of men. We must destroy bourgeois ideology; we must establish proletarian ideology. That is to say in the minds of people, we must finally extinguish all the residues of exploiting classes and exploiting systems. This task is much more difficult than to destroy a class economically, and it can on $1 y$ be resolved by a protracted and complex Lprogram off education and struggle (quoted in Liang Te-nan, 1960:9).

The concept of class struggle is a flexible tool for attacking Chinese traditions. The "bourgeois mentality" and "capitalism" are particularly elastic terms which can be applied to a variety of social and economic practices which could hinder the Communist elite's program of economic development. The "class viewpoint" is used to draw a clear line of demarcation between proletariat (development oriented) thought and bourgeois (tradition oriented) thought. Concretely this might mean that selfish demands on the economic system (the desire for personal gain) would be classified as "bourgeois" while selfless behavior (commitment to community needs) would be considered "proletarian." To "establish proletarian thought against bourgeois thought" was the chief means by which the Chinese leadership waged " a struggle against old customs and habits" (Union Research Service, 1964:62).

While it is widely recognized that capitalism never really evolved in China, the traditional aspiration to own 1 and as the source of all wealth was a strong and conservative force in China. This tradition is criticized under the guise of class struggle.

The peasants have the dual character of the toilers and the small private owners. They are, on the one hand, willing to follow the socialist road, but on the other hand they are conservative and narrow-minded and are spontaneously inclined toward the deep-rooted traditions of capitalism. ... The ideological transformation of the peasants is also a protracted and arduous task (Kuan Ta-t'ung, 1962).

Struggle is an affirmation of the "objective" dialectical process. "Struggle is happiness." According to an article in the Workers Daily:

Chairman Mao has also said: "There is boundless happiness to be found in the struggles against earth and men." Only after one has lived and struggled for the great ideal of communism can he feel that he has lived a significant and happy life (Kan Feng, 1961:6-7).

In the Chinese concept of struggle, conflict against oppressive classes is closely linked to struggle against tradition and the forces of nature (Han Suyin, 1967:126). Class conflict is the means by which contemporary China seeks to achieve economic deve1opment and the Maoist utopian vision. 


\section{Conclusion}

The Promethean quality of the idea of progress gives those who possess it a will, perhaps even a compulsion, to overcome the social and economic obstacles to development. If this Promothean element is present, the social and economic obstacles to development will be overcome. If the dominant elite at the local and national level has a "will to modernize," they will take any steps necessary to remove obstacles to development. If such a "will to modernize" is lacking, then no amount of technical assistance cr foreign aid will remove the obstacles to development. In a sense, this was recognized by a former Peace Corps volunteer writing about his experience.

As in the case of Japan or China, the initial stimulus to development may come from outside - in the shattering influence of a technologically more developed society. But the drive itself depends on a local leadership disciplined enough to forgo its own pleasures in order to promote advancemnt. This is the consideration that should inform all programs of assistance, whether monetary, technical, or human (The Reporter, 1966:61).

A similar conclusion was reached by Kusum Nair after traveling extensively in India. She found distressingly little indication of grassroots involvement in economic development except in the Kaira area of the state of Gujerat. There,

The sharp business acumen, resourcefulness and energy of this Patidar peasantry of Kaira is undeniable and the mean cause of its extraordinary affluence and success. These qualities were further canalized by the nationalist movement for independence which swept the country in the first half of the century. This movement seems to have provided the inspiration, the new norms and values, and the necessary purposeful direction for the corporate effort which made this degree of rural development possible (Kusum Nair, 1962:175-176).

Perhaps one of the most perceptive recognitions of the importance of a "will to modernize" has been stated by a Brazilian who for years sought to answer why his country's economic potential had yet to be realized. He writes:

No, it is not a question of roundly rejecting or denying the past in order to transplant alien formulas, in the way that political regimes, codes, and constitutions have been transplanted. It is now a question of re-examining the past and reinterpreting it in the light of the values and knowledge of the present day, not only to replace those ideal images that remain enthroned upon Brazilian altars long after their proper time has past, but also to hasten the rectification of the master outlines that have presided over the building of the nation ... (Moog, 1964:181-182).

Apparently he means something more than agrarian reform, economic reform, financial reform, and constitutional reform, for he writes:

Certainly Brazil is in need of reforms and achievements of every kind railways and highways, electric power, utilization of waterfalls, immigration of the pioneer type, instead of the bandeirante - all this is being proclaimed daily (Moog, 1964).

What remains to be proclaimed, according to this Brazilian: 
is reform within the mind and spirit. Let us not be deluded. Without a reform of the spirit, without a reaction against the past, without a searching of the national conscience - a great collective self-examination that will make Brazilians realize within themselves, not only intellectually but emotionally, a radical change of ideals and attitudes toward life, their country, and the universe - despite all the prodigious material possibilities that have been knocking at the door so long, Brazil will continue to be what she is: a land that is making progress, but that is not ennobling itself; a land without a message for the world, a disorganized collectivity lacking in moral initiative and public spirit, a disarticulated society permanently hoping for more or less providential miracle-workers or bandeira leaders to come and solve problems that only those communities that are spiritually, morally and constructively integrated know how and are able to solve (1964).

The thought of Mao Tse-tung has placed primary emphasis on the reform of the mind and the spirit. In May, 1958, Liu Shao-ch'i urged his colleagues to recall Mao's wartime dictum that it is man, not material, that counts. Liu also said that:

Ideological and political work is always the soul and guide of every kind of work. ... Some people say that ideological and political work can produce neither grain nor coal nor iron. This is like failing to see the wood for the trees. One may ask: have we not produced more grain, coal and iron by formulating and carrying out correct political lines ... and by raising the socialist consciousness of the workers ... and are we not going to produce more and more by so doing? $(1962: 436-437)$.

This belief that man rather than technology is the key in war or development is the heart of the development strategy of Mao Tse-tung. While the Maoists occasionally over-estimate the utility of ideological mobilization, they have recognized what may be the central element in economic development: the unlimited potentialities of man once his consciousness has been transformed through political activism and social mobilization.

Ideological mobilization in China, like Puritanism in the West, represents a religious fanaticism which leads to an increase in economic productivity. Protestantism sanctioned the supremacy of the individual by rejecting the mediation of a social authority - the Catholic Church - between God and the individual. As Max Weber wrote in The Protestant Ethic and the Spirit of Capitalism, "Man is dominated by the making of money, by acquisition as the ultimate purpose of life" (1956:53). According to this new creed, society and its welfare will be taken care of by automatic forces, by an "invisible hand" that will coordinate self-centered pursuits with the common good. This spirit or faith was for a time carried by a very strong religious movement which purposely set itself apart from the traditions of medieval Christianity. Puritanism gave its religious sanction to material pursuits. Puritanism idealized what had previously been regarded as a lapse from spirtual concerns. What had been chided before as unworthy became a calling of God: to do business, to accumulate, and to lose no time at it. This religiously concelved version of the spirit of capitalism, and not its selfish and materialistic basis, became the Promethean urge that could drive men toward entrepreneurial endeavors in the face of great economic risk and sacrifice. The thought of Mao Tse-tung resembles, in function, the mentality of the Puritans. His calling is not that of God but rather of class, the nation, and the charismatic 
leader. But a calling it is.

This essay has tried to suggest that ideology - a term frequently defined in a pejorative sense - can be useful in the early phases of economic development. Ideology helps initiate the process of development by challenging the ideas and methods of traditional society. It provides an alternative vision of the good society. Once the stability of traditional society has been disrupted, ideology plays a complex and somewhat contradictory role in continuing to disrupt various segments of the old social structure while maintaining the legitimacy and viability of the emerging social structure. Ideology provides the vision and will to mobilize the elite and the populace so that the goals of economic development might be achieved.

Ideology may begin to retard economic development when its evolving latent functions are no longer served by manifest doctrine. Economic development will inevitably create conditions unexplained by the manifest doctrines of the ideology. When this occurs, the latent functions of ideology must adapt to the requirements of the emerging industrial society if ideology is not to impede continued development. For example, while the Puritan ethic of frugality and austerity was essential during the early phases of development, if the American consumer still responded to this ethic, the American economy would probably be plunged into a severe economic crisis. Industrial society requires not frugality and self-sacrifice, but a willingness to consume, an insatiable demand for both goods and services. Among the most serious obstacles to the continued rational development of industrial societies is the invidious influence of their respective ideologies of development.

As suggested at the outset of this article, many observers of contemporary China believe that ideology has already become counter-productive. Perhaps they are correct, but our understanding of the inter-relationship between economic growth and social institutions is still so rudimentary that there is little ground for certitude at this point in time. Industrialization and industrial society may be compatible with a far wider variety of social political processes than we have ordinarily thought. Moreover, it may be unwise to draw generalized conclusions from the temporary economic setbacks of the Great Leap Forward or the Cultural Revolution. In the long-run we may discover that even in their failures, they did much to prepare the Chinese people for industrial society. This may be especially true with respect to the ability of these two movements to disrupt traditional Chinese society, instill a vision of progress, and energize the Chinese and their leaders with a will to overcome the various obstacles to economic development.

\section{Footnotes}

${ }^{1}$ Lifton's statement is only partially correct. The Great Leap assumed that will power and volunteerism could be substituted for technology but only in certain sectors, such as agricultural production, the rural industrial sector, and in rural social overhead investment projects (road and water conservation projects).

${ }^{2}$ As quoted by Lifton, 1968:106. Originally quoted by Schram, 1966:295, quoting Hsueh-hsi Mao Tse-tung ti szu-hsiang fang-fa ho kung-tso fang-fa, Peking, 1958:73.

${ }^{3}$ It is interesting that Mao is today frequently criticized for doing what was widely recognized as necessary a half-century ago. For example, in 1901 Chester Holcombe observed that if Confucius was reduced to "his proper level, as a wise man twenty-five centuries ago, but antiquated and valueless when compared with the needs 
and the leaders of modern days," the "entire Chinese 1iterary aristocracy" would be made bankrupt (The Real Chinese Question:84).

${ }^{4}$ Tuveson suggests that $\operatorname{Kar} 1$ Marx is a successor and intellectual descendant to St. John the Divine and Lord Verulum (1964:vi). For discussions of the Marxist concept of progress, see Meyer, 1963:85-86; Lichtheim, 1961:59-60; Berdyaev, 1960: 99-100, 102-103.

${ }^{5}$ Erik Erikson in referring to the Kibbutz movement in Israel, remarked that this "is one example of a modern ideological utopia which freed unknown energies in young people." See his "The Problem of Ego Identity," 1959:161. The same type of observation was made by an Israeli writer about the earlier settlers on the Second Aliyah (immigration wave). He exclaimed: "What a tremendous energy was released by this Aliyah!" Cited by Aya1, 1966:231. On the futility of outside economic assistance in the absence of such energy see Lampman, 1957:23-29 and Mark Twain's A Connecticut Yankee in King Arthur's Court, especially chaps. 8-10, 22-26.

${ }^{6}$ For articles on the use of class struggle for the elimination of old customs and habits, see Union Research Service, 1964.

References

Aya1, E1iexer

1966 "Nationalist ideology and economic development." Human Organization 25 (Fal1): 231-235.

Babbitt, Irving

1919 Rousseau and Romanticism. Boston: Houghton Miff1in.

Balazs, Etienne

1964 Chinese Civilization and Bureaucracy: Variations on a Theme. New Haven: Yale University Press.

Berdyaev, Nicolas

1960 The Origins of Russian Communism. Ann Arbor: University of Michigan.

Bodde, Derek

1965 China's Cultural Tradition. New York: Holt, Rinehart and Winston.

Cree1, H.G.

1953 Chinese Thought from Confucius to Mao Tse-tung. New York: Mentor Books.

Chiang, Manlin

1947 Tides from the West. New Haven: Yale University Press.

Dah1, Robert A. and Charles E. Lindblom

1963 Politics, Economics, and Welfare. New York: Harper Torchbook.

Daniels, Robert V.

1962 The Nature of Communism. New York: Vintage Books.

Eckstein, Alexander

1970 "Economic development and political change in communist systems." World Politics 22 (July):475-495. 
Elegant, Robert S.

1963 The Centre of the World: Communism and the Mind of China. London: Methuen and Co.

Erikson, Erik

1959 "The problem of ego identity." Psychological Issues 1:101-164.

Fairbank, John King

1962 The United States and China. New York: Viking Press.

Foster, George M.

1965 "Peasant society and the image of 1imited good." American Anthropologist 67 (Apri1) :293-315.

Gayn, Mark

1967 "Mao Tse-tung reassed." Pp.92-108 in Franz Schurmann and Orville Schell (eds.), Communist China. New York: Vintage.

Gerschenkron, Alexander

1962 Economic Backwardness in Historical Perspective, A Book of Essays. Cambridge: Belknap Piess of Harvard University Press.

Han Suyin

1967 China in the Year 2001. New York: Basic Books.

Hightower, James R.

1950 Topics in Chinese Literature: Outlines and Bibliographies. Cambridge: Harvard University Press.

Hirschmeier, Johannes

1964 The Origins of Entrepreneurship in Meiji Japan. Cambridge: Harvard University Press.

Jaspers, Kar1

1953 The Origins and Goal of History. London: Routledge \& K. Paul.

Kan Feng

1961 "Struggle is happiness." The Workers Daily (Peking, September 22) Pp.6-7 in Survey of China Mainland Press, no.2615 (November 8).

Kang Chao

1964 "Economic aftermath of the Great Leap in communist China." Asian Survey 4, (May) : 851-858.

Kuan Ta-t'ung

1962 "How to know the classes and the class struggle of the socialist era." Chung-kuo Ch'ing-nien, nos.20-21 (November 1) in Survey of China Mainland Magazine, no. 342 .

Kusum, Nair

1962 Blossoms in the Dust: The Human Factor in Indian Development. New York:

Frederick A. Praeger.

Lampman, R.J.

1957 "Point IV in 1iterary perspective." Current Economic Comment: 23-29. 
Lewis, John Wilson

1968 "Leader, commissar, and bureaucrat: The Chinese political system in the last days of the revolution." Pp.449-500 in Ping-ti Ho and Tang Tsou (eds.), China in Crisis, vol. 1, book 2. Chicago: University of Chicago Press.

Liang Te-nan

1960 "Correctly understand the law of class struggle in the transitional period and take an active part in the struggle - refuting 'The Theory of Gradual Relaxation of Class Struggle'." Pp.23-24 in Ssu-chuan Ta-hsueh Hsueh-pao 6 (March).

Lichtheim, George

1961 Marxism: An Historical and Critical Study. New York: Frederick A. Praeger.

Lifton, Robert Jay

1968 Revolutionary Immortality: Mao Tse-tung and the Chinese Cultural Revolution. New York: Vintage Books.

Liu Shao-ch'i

1962 "The present situation, the Party's general line for socialist construction and its future tasks." Pp.436-437 in Communist China, 1955-1959. Cambridge:

Harvard University Press.

Meyer, A1fred G.

1963 Marxism: The Unity of Theory and Practice. Ann Arbor: University of Michigan.

Moog, Vianna

1964 Bandeirantes and Pioneers. New York: George Braziller.

Northrop, F.S.C.

1953 The Taming of the Nations. New York: Macmillan.

Pye, Lucian $\mathrm{W}$.

1968 The Spirit of Chinese Politics: A Psychocultural Study of the Authority Crisis in Political Development. Cambridge: The M.I.T. Press.

The Reporter

1966 (December 29): 61.

Rowe, David

1959 Modern China: A Brief History. Princeton, N.J.: Van Nostrand.

Russe11, Bertrand

1922 The Problem of China. London: Allen \& Unwin.

Schram, Stuart R.

1966 Mao Tse-tung. London: Penquin.

1969 "The party in Chinese communist ideology." The China Quarterly 38 (Apri1-June): $1-26$.

Schwartz, Benjamin

1964 In Search of Wealth and Power. Cambridge: Harvard University Press.

Soper, Alexander

1956 The Art and Architecture of China. Baltimore: Penquin. 
Spengler, Joseph J.

1961 "Theory, ideology, non-economic values, and politico-economic development." In Ralph Braibanti and Joseph J. Spengler (eds.) Tradition, Values, and Socio-Economic Development. Durham, N.C.: Duke University Press.

Strong, Anna L.

1964 The Rise of the Chinese People's Communes and Six Years After. Peking: New World Press.

Tuveson, Ernest Lee

1964 Millennium and Utopia: A Study in the Background of the Idea of Progress. New York: Harper Torchbooks.

Twain, Mark (C1emens, Samue1 L.)

1891 A Connecticut Yankee in King Arthur's Court. New York: Webster.

U1 am, Adam

1964 The Unfinished Revolution: An Essay on the Sources of Influence of Marxism and Communism. New York: Vintage Book.

Watkins, F.M.

1951 Review of Kar1 Popper's, The Open Society and Its Enemies. Canadian Journa1 of Economics and Political Science (November) :570.

Weber, Max

1956 The Protestant Ethic and the Spirit of Capitalism. New York: C. Scribner's Sons.

Yang, C.K.

1967 Religion in Chinese Society. Berkeley: University of California Press.

(no author)

1960 Economic, Social, and Political Change in the Underdeveloped Countries. Washington: Government Printing Office.

(no author)

1964 "The elimination of old customs and habits." Union Research Service 37 (October 16): 62 .

(no author)

n.d. The Real Chinese Question. London. 